\title{
Immunohistochemistry for detection of avian infectious bronchitis virus strain M4I in the proventriculus and nervous system of experimentally infected chicken embryos

\author{
Ahmed S Abdel-Moneim*1, Priscila Zlotowski², Jutta Veits³, Günther M Keil ${ }^{3}$ \\ and Jens P Teifke 3
}

\begin{abstract}
Address: ${ }^{1}$ Virology Department, Faculty of Veterinary Medicine, Beni-Suef University, Beni-Suef 62511, Egypt, ${ }^{2}$ Setor de Patologia Veterinária, Faculdade de Veterinária - UFRGS, Av. Bento Gonçalves, 9090, Porto Alegre, RS, Brasil and ${ }^{3}$ Friedrich-Loeffler-Institut (FLI), Federal Research Institute for Animal Health, Südufer 10, 17493 Greifswald-Insel Riems, Germany
\end{abstract}

Email: Ahmed S Abdel-Moneim* - asa@bsu.edu.eg; Priscila Zlotowski - priscavet@hotmail.com; Jutta Veits - jutta.veits@fli.bund.de; Günther M Keil - guenther.keil@fli.bund.de; Jens P Teifke - jens.teifke@fli.bund.de

* Corresponding author

Published: 5 February 2009

Virology Journal 2009, 6:15 doi:10.1186/1743-422X-6-15

This article is available from: http://www.virologyj.com/content/6/I/I5

(c) 2009 Abdel-Moneim et al; licensee BioMed Central Ltd.

This is an Open Access article distributed under the terms of the Creative Commons Attribution License (http://creativecommons.org/licenses/by/2.0), which permits unrestricted use, distribution, and reproduction in any medium, provided the original work is properly cited.
Received: I December 2008

Accepted: 5 February 2009

\begin{abstract}
Background: Infectious bronchitis virus primarily induces a disease of the respiratory system, different IBV strains may show variable tissue tropisms and also affect the oviduct and the kidneys. Proventriculitis was also associated with some new IBV strains. Aim of this study was to investigate by immunohistochemistry (IHC) the tissue tropism of avian infectious bronchitis virus (IBV) strain M4I in experimentally infected chicken embryos.

Results: To this end chicken embryos were inoculated in the allantoic sac with $10^{3} \mathrm{EID}_{50}$ of IBV M4I at 10 days of age. At 48, 72, and $120 \mathrm{~h}$ postinoculation (PI), embryos and chorioallantoic membranes (CAM) were sampled, fixed, and paraffin-wax embedded. Allantoic fluid was also collected and titrated in chicken embryo kidney cells (CEK). The sensitivity of IHC in detecting IBV antigens in the CAM of inoculated eggs matched the virus reisolation and detection in CEK. Using IHC, antigens of IBV were detected in nasal epithelium, trachea, lung, spleen, myocardial vasculature, liver, gastrointestinal tract, kidney, skin, sclera of the eye, spinal cord, as well as in brain neurons of the inoculated embryos. These results were consistent with virus isolation and denote the wide tissue tropism of IBV M4I in the chicken embryo. Most importantly, we found infection of vasculature and smooth muscle of the proventriculus which has not seen before with IBV strain M4I.
\end{abstract}

Conclusion: IHC can be an additional useful tool for diagnosis of IBV infection in chickens and allows further studies to foster a deeper understanding of the pathogenesis of infections with IBV strains of different virulence. Moreover, these results underline that embryonic tissues in addition to CAM could be also used as possible source to generate IBV antigens for diagnostic purposes. 


\section{Background}

Infectious bronchitis virus is the prototype species of the family Coronaviridae in the order Nidovirales. More than 25 genotypes are distributed worldwide. IBV causes an acute highly contagious viral respiratory disease of chickens which is characterized by respiratory rales, coughing and sneezing [1]. Some IBV strains replicate in the gastrointestinal tract, oviduct, and kidney, and due to their nephropathogenic properties they have the potential to cause severe losses with up to $44 \%$ mortality $[1,2]$. In other cases, infection of the proventriculus leads to $75 \%$ to $100 \%$ mortality in young birds [3]. Most isolates of IBV replicate well in the developing chicken embryo following inoculation of the allantoic cavity, and high titers of virus can be isolated from the allantoic fluid [4]. Replication of IBV strains M41 and Beaudette in vitro is restricted to primary chicken cells and depends on the expression of 2,3linked sialic acids on the cell surface. Thus, these molecules are supposed to serve as receptor determinants for primary attachment of IBV to host cells $[5,6]$.

The conventional diagnosis of the IBV is based on virus isolation in embryonated eggs, followed by immunological identification of isolates. Since two or three blind passages are often required for successful primary isolation of IBV, this procedure could be tedious and time consuming. Alternatively, IBV may be isolated by inoculation in chicken tracheal organ cultures. This method is sensitive [7] but highly laborious. Furthermore, IBV may be detected directly in tissues of infected birds by means of immunohistochemistry $[8,9]$ or in situ hybridization[10]. The reverse transcription-polymerase chain reaction (RTPCR) has proved useful in the detection of several RNA viruses [11]. Aim of this study was first to evaluate the suitability of IHC for detection of IBV antigen in paraffinwax embedded CAM and second to analyse the viral antigen distribution in different embryonic tissues between 48 and $120 \mathrm{~h}$ after experimental infection.

\section{Results}

Inoculation of $10^{3} \mathrm{EID}_{50}$ IBV M41 in SPF ECE resulted in death of embryos at $24 \mathrm{~h}$ ( 3 embryos), $41 \mathrm{~h}$ ( 2 embryos) and single embryonic death at 65,87 and $120 \mathrm{~h}$ after IBV inoculation. Allantoic fluid and CAM were harvested at the times given in Table 1 which also showed that high virus titers were obtained 24-87 h PI that decreased sharply to $10^{2} \mathrm{TCID}_{50}$ at $120 \mathrm{~h}$ PI (Table 1). Immunostaining of the CAM was positive in all inoculated eggs from which infectious virus was also recovered. Only one embryo showed non specific death at $24 \mathrm{~h}$ PI as it showed negative results in both immunostaining and virus recovery assays. IHC detected infected CAM that possesses virus titers of only $10^{2}$ or $10^{3} \mathrm{TCID}_{50}$ in the corresponding allantoic fluid (Table 1). IBV antigens were detected in the nasal epithelium, trachea, lung, spleen, myocardium, liver, gizzard, proventriculus, kidney, skin, sclera of the eye, spinal cord, as well as in neurons of the central nervous system in infected embryos (Table 1, Figure 1). Moderate number of positive cells $(++)$ were detected in the mucosa, smooth muscle fibres and vasculature of gizzard at $41,48,65$ and $72 \mathrm{~h}$ PI. Few (+) to moderate (++) number of positive cells were detected in the proventriculus mucosa as well as its smooth muscle fibres in embryos dead at 41,87 and 120 h PI (Figure 1A). Positive immunostaining was also detected in macrophages of both spleen $(41,48,65,72,87 \mathrm{~h} \mathrm{PI})$ (Figure 1C) and liver (Kupffer cells) $(41,48,65,87$ h PI). IBV antigens were also present in neurons of both spinal cord (65 and $72 \mathrm{~h} \mathrm{PI}$ ) and brain (65 and $120 \mathrm{~h} \mathrm{PI}$ ) (Figure 1B), heart (41, 48, 72 h PI) (Figure 1D), nasal cavity $(48,72,87,120$ h PI), lung (41, 87 h PI), skin $(48,87,120$ h PI), eye sclera (65 h PI). In the kidney, viral proteins were detected in both renal tubules (72 h PI) and glomeruli (41, 48, 87 h PI) Table 1.

\section{Discussion}

Classic methods for IBV diagnosis include serological tests for analysis of antibody titers against IBV [12] and virus isolation in embryonated chicken eggs since IBV grows well in the developing chicken embryo. These methods are inherently slow and time consuming. Currently, detection and serotype analysis of IBV is performed by RT-PCR and restriction fragment length polymorphism analysis [13] or by sequencing RT-PCR products of S1 gene [14]. To establish IHC on paraffin-wax embedded tissues using a polyclonal rabbit anti-IBV serum, embryonated eggs were inoculated with $10^{3} \mathrm{EID}_{50}$ IBV M41. CAM and embryos were collected till $120 \mathrm{~h} \mathrm{PI}$, since the presence of IBV antigen in inoculated eggs by an antigen detection method is preferably performed 2 to 3 days after inoculation [15]. This also confirmed in the current study where IBV titers declined sharply at $120 \mathrm{~h}$ PI. It is well known that maximum IBV virus titers reached 1 to 2 days postinoculation [16-18] but interestingly, allantoic fluid showed high virus titers $24-87 \mathrm{~h}$ PI. Immunostaining of the CAM was positive in all inoculated eggs from which infectious virus was recovered. It is worth to note that also samples of infected CAM with respective allantoic fluid virus titers of only $10^{2}$ or $10^{3} \mathrm{TCID}_{50}$ were obtained, stained positively with the IBV antiserum which equals approximately $10^{4}$ or $10^{5} \mathrm{EID}_{50}$ [19]. This indicates a relatively high sensitivity of the immunohistochemistry applied in this study. Using a monoclonal antibody for immunostaining, the detection limit for IBV antigen was $10^{6.2} \mathrm{EID}_{50}$ as described by [20]. These differences in sensitivity may be due to larger number of antigenic epitopes recognized by the polyclonal serum. This finding prompted us to apply IHC for screening of antigen distribution in different tissues in the IBV inoculated embryos. Antigens were detected in the nasal epithelium, trachea, lung, spleen, myocardium, liver, gizzard, proventriculus, 


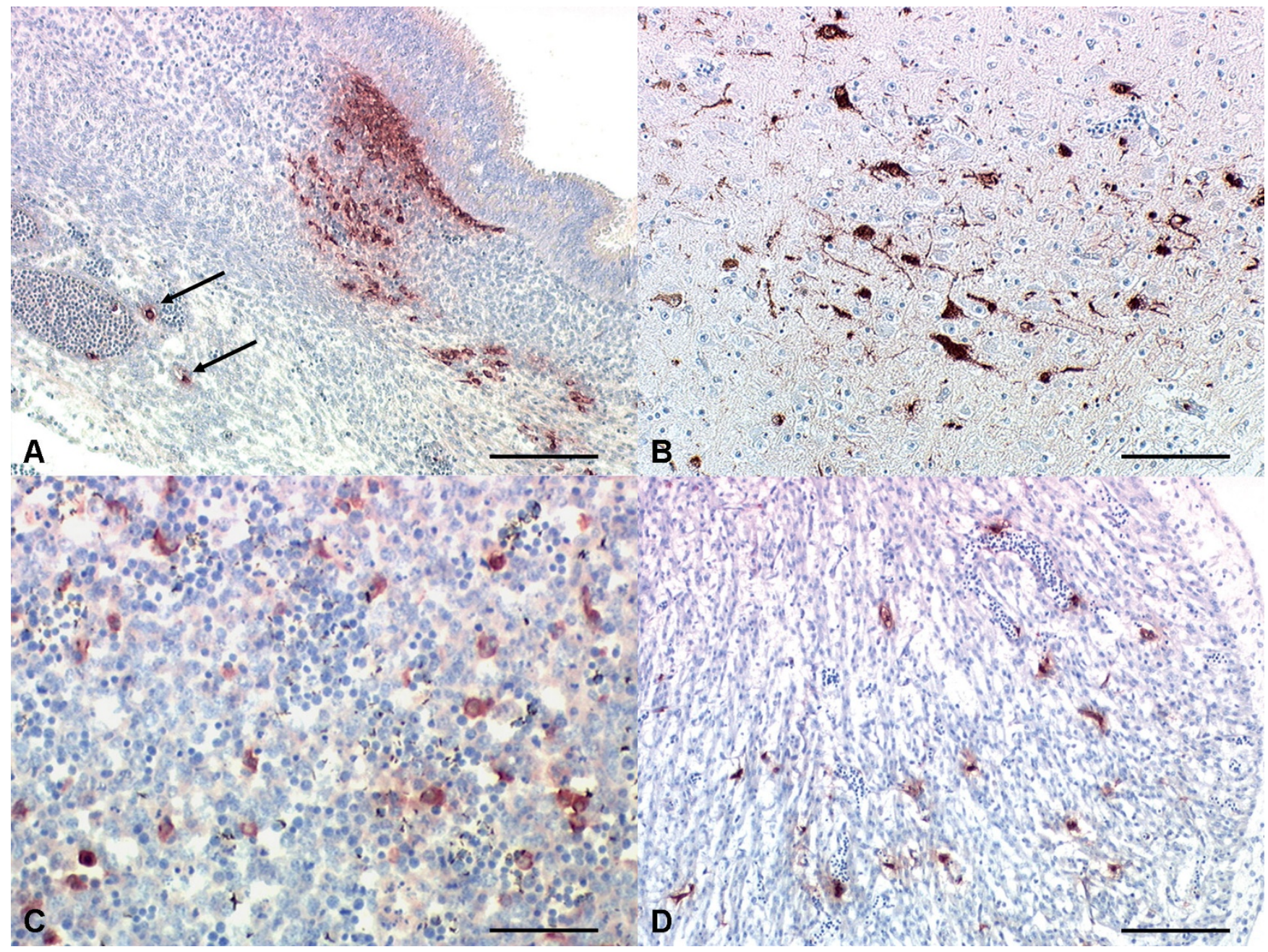

\section{Figure I}

Immunohistochemical detection of IBV antigens in chicken embryos after experimental infection with IBV M4I. (A) Proventriculus, focally extensive, there is strong immunolabelling of smooth muscle cells and scattered cells within the vasculature (arrows). Bar $=100 \mu \mathrm{m}$ (B) Brain, within the cytoplasm of numerous neurons there is strong staining of IBV antigen. Bar $=40 \mu \mathrm{m}(\mathrm{C})$ Spleen, scattered through the parenchyma there are numerous singular polygonal cells with red intracytoplasmic staining for IBV antigen, interpreted to be macrophages. Bar $=40 \mu \mathrm{m}$ (D) Myocardium, capillary endothelium stains strongly positive for IBV antigen. Bar $=100 \mu \mathrm{m}$.

kidney, skin, sclera of the eye, spinal cord, as well as in neurons of the central nervous system in infected embryos. However, isolation or detection of virus by virological methods may indicate only that virus is present in the tissue due to viraemia and thus does not necessarily prove productive replication in the respective organs. Hence, tissue tropism can not be determined by virus isolation or detection only [21] but requires morphologically based techniques. Although Chong \& Apostolov [22], failed to detect virus by immunofluorescence in the intestine and cecal tonsils of chickens experimentally infected with M41 of IBV, Lucio \& Fabricant [23] found that M41 can infect a variety of tissues and that some isolates may be recovered frequently from the digestive tract. IBV infec- tion of the proventriculus was firstly recorded in China [3] then detected with UNAM-97 IBV Mexican variant that produced decrease in the proventricular gland papillary branching and electrodense material scattered in proventriculus with a structure consistent with coronaviruses [24]. To the best of our knowledge, this is the first time that the prototype IBV strain M41 was also detected within the muscle layer of the proventriculus. Because IBV causes an upper respiratory tract disease, viral antigens in nasal mucosa, trachea and lung were expected. IBV M41 viral antigen was found in the renal tubules and glomeruli. This observation is consistent with the finding that IBV M41 has also been isolated and/or detected in kidneys of naturally or experimentally inoculated chickens 
Table I: Detection of IBV in CAM and chicken embryo.

\begin{tabular}{|c|c|c|c|c|}
\hline Sample No. & Time after inocul ation ( $\mathrm{h} \mathrm{Pl}$ ) & Embryo status & Results of Immunohistochemistry & Virological findings $\ddagger\left(\mathrm{TCID}_{50} / \mathrm{ml}\right)$ \\
\hline I & 24 & Dead & CAM - & 0 \\
\hline 2 & 24 & Dead & $\mathrm{CAM}+$ & 104.5 \\
\hline 3 & 24 & Dead & $\mathrm{CAM}+$ & $10^{4.5}$ \\
\hline 4 & 41 & Dead & $\mathrm{CAM}+$ & $10^{4}$ \\
\hline \multirow[t]{8}{*}{5} & 41 & Dead & $\mathrm{CAM}+$ & $10^{3}$ \\
\hline & & & Gizzard (smooth muscle, vasculature) ++ & \\
\hline & & & Heart (vasculature) ++ & \\
\hline & & & Kidney (glomerular tufts) ++ & \\
\hline & & & Liver (Kupffer cells) ++ & \\
\hline & & & Lung (vasculature) ++ & \\
\hline & & & Proventriculus (smooth muscle) ++ & \\
\hline & & & Spleen (macrophages) + & \\
\hline \multirow[t]{8}{*}{6} & 48 & Alive & $\mathrm{CAM}+$ & $10^{4}$ \\
\hline & & & Gizzard ++ & \\
\hline & & & Heart (vasculature) ++ & \\
\hline & & & Kidney (glomerular tufts) ++ & \\
\hline & & & Liver (Kupffer cells) + & \\
\hline & & & Lung ++ & \\
\hline & & & Proventriculus + & \\
\hline & & & Spleen (Macrophages) +++ & \\
\hline \multirow[t]{3}{*}{7} & 48 & Alive & CAM + & $10^{6}$ \\
\hline & & & Nasal mucosa (epithelium) ++ & \\
\hline & & & Skin (epidermis) + & \\
\hline \multirow[t]{3}{*}{8} & 48 & Alive & $\mathrm{CAM}+$ & $10^{5}$ \\
\hline & & & Nasal mucosa (epithelium) ++ & \\
\hline & & & Skin (epidermis) + & \\
\hline \multirow[t]{7}{*}{9} & 65 & Dead & Brain (neurons) + & $10^{5}$ \\
\hline & & & CAM: + & \\
\hline & & & Eye (sclera) + & \\
\hline & & & Gizzard ++ & \\
\hline & & & Liver + & \\
\hline & & & Spinal cord (neurons) + & \\
\hline & & & Spleen (Macrophages) ++ & \\
\hline \multirow[t]{8}{*}{10} & 72 & Alive & CAM: + & $10^{6}$ \\
\hline & & & Gizzard (mucosa) ++ & \\
\hline & & & Heart (vasculature) & \\
\hline & & & Kidney (tubuli) + & \\
\hline & & & Nasal cavity (mucosa) +++ & \\
\hline & & & Skin (epidermis) ++ & \\
\hline & & & Spinal cord (neurons) + & \\
\hline & & & Spleen (macrophages) ++ & \\
\hline \multirow[t]{8}{*}{11} & 87 & Dead & $\mathrm{CAM}+$ & $10^{5}$ \\
\hline & & & Kidney (glomeruli) + & \\
\hline & & & Liver (Kupffer cells) + & \\
\hline & & & Lungs (epithelium, vasculature) + & \\
\hline & & & Nasal cavity (mucosa)++ & \\
\hline & & & Proventriculus (smooth muscle, mucosa) ++ & \\
\hline & & & Skin (epidermis) ++ & \\
\hline & & & Spleen (macrophages) +++ & \\
\hline \multirow[t]{6}{*}{12} & 120 & Dead & Brain (neurons) + & $10^{2}$ \\
\hline & & & $\mathrm{CAM}+$ & \\
\hline & & & Nasal cavity (mucosa) ++ & \\
\hline & & & Proventriculus (mucosa) + & \\
\hline & & & Skin (epidermis) ++ & \\
\hline & & & Trachea (mucosa) ++ & \\
\hline
\end{tabular}

Results of immunohistochemistry and virus reisolation.

Intensity of immunostaining: - (negative $=$ no positive cells $),+($ weak $=$ small number of positive cells per high power field $),++($ moderate $=$ moderate number of positive cells per HPF), +++ (strong = accentuated staining pattern with large numbers of positive cells per HPF); CAM: chorioallantoic membrane.

$\ddagger$ Allantoic fluid from respective embryo was titrated in chicken embryo kidney cell culture and virus titter was expressed as $\mathrm{TCID}_{50}$. 
$[23,25,26]$. As earlier described for other IBV genotypes, antigens of M41 were present not only in renal tubules, but also in the glomerular tuft epithelium [27]. The detection of IBV antigen in the spleen, is discussed controversially in the literature. In some reports, IBV antigens or mRNA were not found within the spleen [28-30], in others, splenic infection was observed $[27,31,32]$. Studies to determine virus distribution in embryonic tissues were conducted previously $[29,30]$ indicating that IBV antigen or nucleic acid was present in trachea, bursa, kidney, intestine, lung, heart, esophagus, mesentery, shell gland, and air sac, but not in spleen or thymus. The different virus distribution between the present paper and other papers may be due to the difference of embryo age at inoculation; 10 days old embryos (present paper) and 17 or 18 days old embryos $[29,30]$. It is probable that more immature tissues are more susceptible for IBV. The susceptibility for IBV infection is associated with the expression of 2,3linked sialic acid which is used by the virus for primary attachment to the cell surface $[5,6]$. For tight binding and subsequent fusion with the cellular membrane interaction with a second receptor appears to be required [5]. The initial target of avian influenza viruses and IBV in chicken is the respiratory epithelium. Presence of 2,3-linked sialic acid is the prerequisite for avian influenza viruses to initiate respiratory infection. This molecule may also be used by IBV for infection of the respiratory tract. IBV, like avian influenza viruses, infects many non-respiratory tissues, including alimentary tract, oviduct and kidney $[33,34]$. The broad distribution of 2,3-linked sialic acid in different organs and species contradicts the view that this type of sugar is a major determinant of the narrow host tropism of IBV. In this study IBV antigen was found in musculature of both gizzard and proventriculus of inoculated embryos which is consistent with the known presence of 2,3-linked sialic acid receptors in the intestinal tract of chicken [35]. Thus it raises the question whether IBV infection of the proventriculus is a classic feature of IBV and occurs in association with an old IBV strain. A recently isolated M41 strain [26] resulted in an increased proventriculus index 7-28 days after experimental infection of 1-day-old chickens [Mohamed AA: Studies on infectious proventricultis in broiler chicken. Master thesis, In progress].

For our knowledge, IBV was neither isolated from nor detected in the brain of young or adult chickens [32]. Our finding that IBV antigens are present in the nervous system of embryonic chicken, may be explained by the presence of polysialylated N-CAM (neural cell adhesion molecules) in chicken embryos which might mediate virus entry into the neurons. The abundance of polysialylated N-CAM declines gradually during the embryonic development and the synthesis dramatically decreases right before birth [36,37].

\section{Conclusion}

Our results show that the classic IBV strain M41 exhibits a wide tissue tropism including the nervous system and the proventriculus in chicken embryos and demonstrate that IHC as described here is a very sensitive tool for detection of productive virus replication in situ and therefore allows further studies to improve the understanding of the pathogenesis of the IBV infection.

\section{Methods \\ Cells and viruses}

The IBV strain M41 used in the current study was kindly provided by $M$. Hess, Intervet, Boxmeer, NL. Chicken embryo kidney cells (CEK) were prepared from specific pathogen free (SPF) embryonated chicken eggs (ECE) as described elsewhere [38]. Briefly, kidneys from 18-dayold SPF ECE were isolated, washed with Hanks' balanced salts solution, minced and disaggregated in trypsin solution. After centrifugation the cells were resuspended in Dulbeccos' modified Eagle's medium (DMEM) supplemented with $10 \%$ fetal calf serum (FCS) and grown at $37^{\circ} \mathrm{C}$ in a $5 \% \mathrm{CO}_{2}$ incubator to confluent monolayers.

\section{Inoculation of embryonated eggs}

Twelve ten days old SPF ECE were inoculated in the allantoic sac with $200 \mu \mathrm{l}$ of IBV strain M41(103 $\left.\mathrm{EID}_{50}\right)$. Inoculated ECE were candled twice daily. At 48, 72, or $120 \mathrm{~h}$ dead and/or living whole embryos as well as allantoic fluid and CAM were collected. Embryos died at any time after inoculation, were also sampled accordingly. The allantoic fluid of inoculated eggs was harvested and clarified by centrifugation for $10 \mathrm{~min}$ at $925 \mathrm{~g}$. The obtained supernatants were used for titration in CEK.

\section{Immunohistochemistry}

The presence of IBV antigens was investigated in CAM and embryos using the avidin-biotin complex (ABC) method for immunohistochemistry [39]. To this end, sampled CAM and individual whole embryos, containing all organs were fixed for $4 \mathrm{~h}$ in Carnoy solution (absolute ethyl alcohol:chloroform:acetic acid; 6:3:1) followed by dehydration in absolute ethanol, and paraffin waxembedding. Sections were cut at $2 \mu \mathrm{m}$, and mounted on electrostatically charged glass slides. Tissue sections (CAM and whole embryos cut in transversal or sagittal orientation) were dewaxed in xylene, rehydrated, treated with $3 \%$ hydrogen peroxide and then subjected to antigen retrieval by microwaving in $10 \mathrm{mM}$ citric buffer ( $\mathrm{pH} \mathrm{6.0)}$ for 10 min. Treated slides were cooled at room temperature for $20 \mathrm{~min}$. Non specific background staining was blocked by incubating the sections for $20 \mathrm{~min}$. with goat serum. The sections were then incubated for $1 \mathrm{~h}$ with 1:3000 rabbit anti-IBV polyclonal serum (prepared previously in the laboratory of G. Keil, FLI, using purified IBV M41) in Tris buffered saline (TBS), 1\% bovine serum albumin (BSA), 
followed by $30 \mathrm{~min}$. incubation with each of 1:200 biotinylated goat anti-rabbit immunoglobulin and subsequent extra avidin peroxidase conjugate. To visualize bound antibodies, the sections were then incubated in aminoethyl-carbazole substrate chromogen (DakoCytomation, Hamburg, Germany) for 10 min. Finally, the sections were counter-stained with Mayer's haematoxylin and mounted with aqueous mounting medium. The staining intensities observed microscopically were divided into four grades: $-($ negative $=$ no positive cells $),+($ weak $=$ small number of positive cells per high power field [HPF, approx. $400 \times]),++($ moderate $=$ moderate number of positive cells per HPF,+++ (strong $=$ accentuated staining pattern with large numbers of positive cells per HPF). In each tissue 10 randomly selected areas of each compartment were evaluated at high power by light microscopy. The judgments were made semiquantitatively via side-byside comparisons of one section to another and the purpose was to evaluate antigen distribution in relation to labelling intensity in different embryonic tissues.

\section{Virus titration}

$100 \mu \mathrm{l}$ of tenfold serial dilutions in MEM were added to $10^{5} \mathrm{CEK}$ cells per well. After $48 \mathrm{~h}$ of incubation, cells were fixed with acetone-methanol, and virus titers expressed as tissue culture infective dose fifty $\left(\mathrm{TCID}_{50}\right)$ were determined by indirect immunofluorescence using a polyclonal serum raised in rabbits against purified IBV M41 virions.

\section{Indirect immunofluorescence}

IBV infected CEK cells were fixed with acetone-methanol for $15 \mathrm{~min}$. After washing, cells were incubated with the polyclonal rabbit anti-IBV serum (1:2000) for $1 \mathrm{~h}$ and subsequently with FITC-conjugated goat anti-rabbit antibodies (Sigma) (1:2000) for $1 \mathrm{~h}$. Both primary and secondary antibodies were diluted in PBS. Plates were rinsed three times with PBS after each step.

\section{Competing interests}

The authors declare that they have no competing interests.

\section{Authors' contributions}

ASA performed virus inoculation in ECE and cell culture, IFA, contributed to IHC, analyzed the data, and drafted the manuscript. PZ contributed to IHC and histopathological examination, JV performed virus isolation and IFA. GMK and JPT initiated the project, provide continued directions and critically reviewed the manuscript. JPT also performed and supervised histopathology and IHC. All authors read and approved the final manuscript.

\section{Acknowledgements}

We thank Katrin Giesow and Gabriele Czerwinski for excellent technical assistance.

\section{References}

I. Cavanagh D, Naqi S: Infectious bronchitis. In Diseases of Poultry I Ith edition. Edited by: Saif YM, Barnes HJ, Glisson JR, Fadly AM, McDougald LR, Swayne DE. Ames: lowa State University Press; 2003:101-119.

2. Cavanagh D: Coronaviruses in poultry and other birds. Avian Pathol 2005, 34:439-448.

3. Yu L, Jiang Y, Low S, Wang Z, Nam SJ, Liu W, Kwang J: Characterization of three infectious bronchitis virus isolates from China associated with proventriculus in vaccinated chickens. Avian Dis 2001, 45:416-424.

4. McMartin DA: Infectious bronchitis. In Virus Infections of Vertebrates. Virus Infections of birds Edited by: McFerran JB, McNulty MS. Amsterdam: Elsevier Science Publishers; 1993:249-275.

5. Winter C, Schwegmann-Weßels C, Cavanagh D, Neumann U, Herrler G: Sialic acid is a receptor determinant for infection of cells by avian Infectious bronchitis virus. J Gen Virol 2006, 87: $1209-1216$.

6. Winter C, Herrler G, Neumann U: Infection of the tracheal epithelium by infectious bronchitis virus is sialic acid dependent. Microbes Infect 2008, I0(4):367-373.

7. Cook JKH, Darbyshire JH, Peters RW: The use of chicken tracheal organ cultures for isolation and assay of avian bronchitis. Arch Virol 1976, 50:109-II8.

8. Nakamura K, Cook JKA, Otsuki K, Huggins MB, Frazier JA: Comparative study of respiratory lesions in two chicken lines of different susceptibility infected with infectious bronchitis virus: histology, ultrastructure and immunohistochemistry. Avian Pathol 199I, 20:24I-257.

9. Chen BY, Hosi S, Nunoya T, Itakura C: Histopathology and immunohistochemistry of renal lesions due to infectious bronchitis virus in chicks. Avian Pathol 1996, 25:269-283.

10. Collisson EW, Li J, Sneed LW, Peters ML, Wang L: Detection of avian infectious bronchitis using in situ hybridization and recombinant DNA. Vet Microbiol 1990, 24:26|-27|.

II. Cavanagh D, (Ed): Advances in avian diagnostic technology. Xth WId Vet Poult Assoc Congress. Sydney 1993:57-70.

12. Lukert PD: Infectious bronchitis. In Isolation and identification of avian pathogens 2 nd edition. Edited by: Hitchner SB, Domermuth $\mathrm{CH}$, Purchase HG, Williams JE. American Association of Avian Pathologists, Kennett Square, PA; 1980:70-72.

13. Kwon HM, Jackwood MW, Gelb J Jr: Differentiation of infectious bronchitis virus serotypes using polymerase chain reaction and restriction-fragment-length polymorphism analysis. Avian Dis 1993, 37:194-202.

14. Kingham BF, Keeler CL Jr, Nix WA, Ladman BS, Gelb J Jr: Identification of avian infectious bronchitis virus by direct automated cycle sequencing of the S-I gene. Avian Dis 2000, 44:325-335.

15. De Wit J]: Detection of infectious bronchitis virus. Avian Pathol 2000, 29:7I-93.

16. Purchase HG, Cunningham $\mathrm{CH}$, Burmester BR: Genetic differences among chicken embryos in response to inoculation with an isolate of infectious bronchitis virus. Avian Dis 1966 , I0:162-172.

17. Clarke JK, McFerran JB, Gay FW: Use of allantoic cells for the detection of avian infectious bronchitis virus. Archiv fur die Gesamte Virusforschung 1972, 36:62-70.

18. Darbyshire JH, Cook JKA, Peters RW: Comparative growth kinetic studies on avian infectious bronchitis virus in different systems. J Comp Pathol 1975, 85:623-630.

19. Ferreira HL, Pilz D, Mesquita LG, Cardoso T: Infectious bronchitis virus replication in the chicken embryo related cell line. Avian Pathol 2003, 32:413-4I7.

20. Naqi SA: A monoclonal antibody-based immunoperoxidase procedure for rapid detection of infectious bronchitis virus in infected tissues. Avian Dis 1990, 34:893-898.

21. Hofstad MS, Yoder HW Jr: Avian infectious bronchitis virus distribution in tissues of chicks. Avian Dis 1966, 10:230-239.

22. Chong $\mathrm{KT}$, Apostolov $\mathrm{K}$ : The pathogenesis of nephritis in chicks induced by infectious bronchitis virus. J Comp Pathol 1982, 92:199-2।I.

23. Lucio B, Fabricant J: Tissue tropism of three cloacal isolates and Massachusetts strain of infectious bronchitis virus. Avian Dis 1990, 34:865-870.

24. Escorcia M, Fortoul TI, Petrone VM, Galindo F, López C, Téllez G: Gastric gross and microscopic lesions caused by the UNAM- 
97 variant strain of infectious bronchitis virus after the eighth passage in specific pathogen-free chicken embryos. Poult Sci 2002, 8 I : 1647-1652.

25. Jones RC: Nephrosis in laying chickens caused by Massachusetts-type infectious bronchitis virus. Vet $\operatorname{Rec} 1974, \mathbf{5 : 3 1 9 .}$

26. Abdel-Moneim AS, El-Kady MF, Ladman BS, Gelb J Jr: SI gene sequence analysis of a nephro-pathogenic strain of avian infectious bronchitis virus in Egypt. Virol J 2006, 3:78.

27. Abdel-Moneim AS, Madbouly HM, El-Kady MF: In vitro characterization and pathogenesis of Egypt/Beni-Suef/O I; a novel genotype of infectious bronchitis virus. Beni-Suef Vet Med J Egypt 2005, 15:127-133.

28. Ambali AG, Jones RC: Early pathogenesis in chicks of infection with an enterotropic strain of infectious bronchitis virus. Avian Dis 1990, 34:809-817.

29. Kapczynski DR, Sellers HS, Rowl GN, Jackwood MW: Detection of in ovo-inoculated infectious bronchitis virus by immunohistochemistry and in situ hybridization with a riboprobe in epithelial cells of the lung and cloacal bursa. Avian Dis 2002, 46:679-685.

30. Lee C-W, Brown C, Jackwood MW: Tissue distribution of avian infectious bronchitis virus following in ovo inoculation of chicken embryos examined by in situ hybridization with antisense digoxigenin-labeled universal riboprobe. J Vet Diag Invest 2002, | 4:377-38I.

31. Cumming RB: The control of avian infectious bronchitis/nephrosis in Australia. Aust Vet J 1969, 45:200-203.

32. Naqi S, Gay K, Patalla P, Mondal S, Liu R: Establishment of persistent avian infectious bronchitis virus infection in antibodyfree and antibody-positive chickens. Avian Dis 2003, 47:594-60I.

33. Casais $R$, Dove $B$, Cavanagh $D$, Britton P: Recombinant avian infectious bronchitis virus expressing a heterologous spike gene demonstrates that the spike protein is a determinant of cell tropism. J Virol 2003, 77:9084-9089.

34. Liu S, Kong X: A new genotype of nephropathogenic infectious bronchitis virus circulating in vaccinated and nonvaccinated flocks in China. Avian Pathol 2004, 33:321-327.

35. Guo C-T, Takahashi N, Yagi H, Kato K, Takahashi T, Yi S-Q, Chen Y, Ito T, Otsuki K, Kida H, Kawaoka Y, Hidari KI, Miyamoto D, Suzuk T, Suzuki Y: The quail and chicken intestine have sialyl-galactose sugar chains responsible for the binding of influenza $A$ viruses to human type receptors. Glycobiology 2007 I 7(7):7|3-724.

36. Oka S, Bruss JL, Nelson RW, Rutishauser U: Properties and developmental regulation of polysialyltransferase activity in the chicken embryo brain. J Biol Chem 1995, 270:19357-19363.

37. Ong E, Nakayama J, Angata K, Reyes L, Katsuyama T, Arai Y, Fukuda $M$ : Developmental regulation of polysialic acid synthesis in mouse directed by two polysialyltransferases, PST and STX. Glycobiology 1998, 8(4):415-424.

38. Schat KA, Purchase HG: Cell culture methods. In A laboratory manual for isolation and identification of avian pathogens 4th edition. Edited by: Swayne DE, Glisson JR, Jackwood MW, Pearson JE, Reed WM. American Association of Avian Pathologists, Kennett Square, PA; 1998:223-234.

39. Luppi PH, Fort $\mathrm{P}$, Jouvet $\mathrm{M}$ : Iontophoretic application of unconjugated cholera toxin $B$ subunit (CTb) combined with immunohistochemistry of neurochemical substances: a method for transmitter identification of retrogradely labeled neurons. Brain Res 1990, 534:209-224.
Publish with Bio Med Central and every scientist can read your work free of charge

"BioMed Central will be the most significant development for disseminating the results of biomedical research in our lifetime. "

Sir Paul Nurse, Cancer Research UK

Your research papers will be:

- available free of charge to the entire biomedical community

- peer reviewed and published immediately upon acceptance

- cited in PubMed and archived on PubMed Central

- yours - you keep the copyright
BioMedcentral 